\section{Ethical Lingua}

Journal of Language Teaching and Literature

ISSN 2355-3448 (Print)

ISSN 2540-9190 (Online)

Volume 4, Number 2, August 2017

pp. $176-183$.

\title{
The Correlation between Students' L2 Motivation and Their EFL Proficiency
}

\author{
Purnama Cahya \\ purnamacahya@uncp.ac.id \\ Universitas Cokroaminoto Palopo, Indonesia \\ Accepted : 17 August 2017 \\ URL $\quad$ : http://journal.uncp.ac.id/index.php/ethicallingua/article/view/633
}

\begin{abstract}
This study is intended to find the correlation between students L2 motivation and their EFL proficiency. The Instruments used in this current study involved questionnaire and test. The questionnaire is used to measure the students' motivation and the test was used to reveal student's EFL proficiency score. The current study involves 195 college students from four universities in Malang. The result of analysis shows that there is a significant correlation between L2 motivation and the students' EFL proficiency. It is proved by the test of hypothesis in which $P$ Value $(0.002)$ is lower than Alfa $(\alpha=0.01)$. The result implies the increase in students' motivation can be a prediction of the increase of students' EFL proficiency. The students who are strongly motivated in learning English are most probably achieve better in their EFL proficiency.
\end{abstract}

Keywords: L2 Motivation, EFL Proficiency

\section{Introduction}

There are many factors which may affect teaching and learning process. From cognitive to affective, in order to be an advance language learner, students need both cognitive and affective aspects (Graham, 1997). The cognitive is the ability to adapt to new demands and approaches involving new learning strategies and pattern of working to adjust the situation. However, it was also emphasized the influence of affective factors on how well a foreign language is acquired. Renandya (2013) selected eight important factors that can influence L2 students' acquisition of English proficiency. Furthermore, he proposed a framework based on current beliefs and the implication in teaching EFL. He called it 'FLAMINGOS' which stood for fluency, amount and intensity, motivation, input, output and set of phrases. Among those variables mentioned in the framework, motivation which is one of affective factors has been discussed and deemed as the main predictor in the success of L2 learning. 
Affective factors can be identified as motivation, anxiety, self-esteem, personality and etc., they play a significant role in foreign language learning. Even though there is no certain separation of elements in affective factors since they often overlap one another, the work of Yokochi (2003) can be referred to explain those factors. In her critical review paper, seven categories of affective factors are gathered and discussed. The factors involve acculturation, ego, personality, emotion, beliefs about learning, attitudes, and motivation. In her paper, she also listed the study involving affective factors by first author and year and it was shown that attitude and motivation are the most commonly included factors. Self esteem and anxiety are found in the further explanation of emotion. Affective factors which may have impacts on foreign language learning have been researched since around the late 1980's (Takahashi \& Takahashi, 2013). These factors include motivation, anxiety, attitudes, tolerance of ambiguity, risk-taking tendencies, and so forth, and studies dealing with them have achieved certain degrees of results in the field of teaching English as a second/foreign language (ESL/EFL)

Sikhwari (2007) conducted a research to investigate the relationship between affective factors and the academic achievement of students at the University of Venda. In the study, the affective factors selected are self-concept, motivation and attitude. The general aim of the study is to determine the role of self-concept, motivation and attitude in students' academic achievement and ultimately come up with some recommendations for enhancing these factors. The theoretical investigation indicates that there is a relationship between students' self-concepts, motivation, attitude, and academic achievement. Similarly, the empirical investigation has revealed that there is a significant correlation between self-concept, motivation, and academic achievement of students. This study by Sikhwari (2007) has brought the idea of the importance of affective variables towards language learning output. However, there is also a need to investigate the interrelatedness of affective factors which has not been studied in the study. Therefore, in this current research, the four selected aspects of affective factors which are anxiety, motivation, self-esteem and attitude will be taken into account. This research will investigate the model of their relationships in relation to their level of priority in affecting the EFL proficiency.

To highlight the importance of motivation as the contributing factors in second language learning, Norris (2001), in his paper, has tried to explore Gardner's socio-educational model and the significance of motivation as a contributing factor in second language (L2) acquisition. He also classified motivation into two; integrative and instrumental. The former is characterized by the learner's positive attitudes towards the target language group and the desire to integrate into the target language community. Meanwhile, the latter underlies the goal to gain some social or economic reward through $\mathrm{L} 2$ achievement, thus referring to a more functional reason for language learning. The two types of motivation are important in defining the language learners' success in second language acquisition (SLA).

Motivation is a general term used in many contexts. In the area of language education Dornyei (2009) defines it as the most important concepts in 
psychology as well as L2 teaching because it is one of the variables often referred by teachers and students in explaining success and failure in learning. Renandya (2015) stated that motivation is perhaps the single most important factor affecting the outcome of L2 learning.

There is a threshold proficiency level the teacher needs to have reached in the target language in order to be able to teach effectively in English. A teacher who has not reached this level of proficiency will be more dependent on teaching resources and less likely to be able to engage in improvisational teaching (Richards, 2010). In the result of study on relationship between English proficiency and academic success in international postgraduate education conducted by Vinke \& Jochems (1993), they revealed that the improvement of English proficiency to a certain extent might increase the possibility of being academically successful. In their study, they made use of TOEFL score as the representation of English proficiency. Nowadays, Test of English as Foreign Language or TOEFL, as one of widely acknowledged version of English proficiency test for non-native users, has been used by not only International educational institution but also by several domestic higher learning institution as well as non educational agencies as a requirement of either admission, recruitment, or exit purpose (Sulistyo, 2009).

In this current study, it will attempt at finding the empirical evidence of the correlation of motivation which believed as then main factors that affect proficiency. Nowadays students' EFL proficiency is one of qualifications for their academic success in the future. As stated by Genç \& Bada, E (2010), English has role as global language in which it has become one of the most important academic and professional tools. That is what makes most of academic publishing as the primary source for students is mostly written in English. Moreover, for EFL students majoring in ELT, their proficiency in English must be adequate because, as EFL teachers later on, they are required to have competency not only in pedagogy but also in knowledge about the language.

\section{Methodology}

This research were initiated by distributing questionnaires motivation and then a test administered to measure students' EFL proficiency. Based on the research problems, the direction of the relationship of those variables mentioned previously can be seen on the following figure. The relationship between variables is shown in form of arrows.

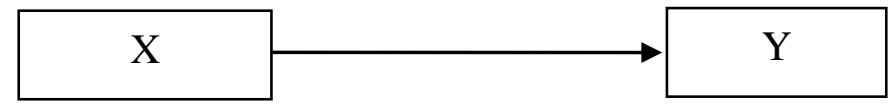

Figure 1. Correlation between students' motivation and EFL proficiency

$$
\begin{array}{ll}
\text { Legend: } & X=\text { motivation } \\
& Y=E F L \text { proficiency }
\end{array}
$$




\section{Population and Sample}

The population of the current study is the college students in Indonesia. All those students in Indonesia must learn English as foreign language. Their proficiency, motivation and their major area are varied. As for the sample, this study involves 195 students for four universities in Malang. Here is the list of the research samples;

Table 1. Information of Participants' Major and Universities

\begin{tabular}{|c|c|c|}
\hline No & Universities & Students' Major \\
\hline 1 & State University of Malang (UM) & English Literature (44 students) \\
\hline 2 & $\begin{array}{l}\text { University of Muhammadiyah Malang } \\
\text { (UMM) }\end{array}$ & $\begin{array}{l}\text { Management (33 students), Electrical } \\
\text { Engineering (26) }\end{array}$ \\
\hline 3 & Kanjuruhan University (UNIKAMA) & ELT (23 students), Mathematic (93) \\
\hline 4 & STIKES Widya Cipta Husada & Nutrition (20 students) \\
\hline
\end{tabular}

\section{Research Instruments}

There are two kinds of primary instrument which are used in this study. They are questionnaire and the Test of English as a Foreign Language (TOEFL) test as measurement of EFL proficiency. To collect data in this study, there are two kinds of research instrument are used; a paper based TOEFL and a set of questionnaire on students' affective factors. In order to measure students' EFL proficiency, a test adapted from a paper-based version of TOEFL test will be conducted. TOEFL is used because it is most likely to be the common proficiency test used widely in Indonesia, as stated by Sulistyo (2009), TOEFL is one of widely acknowledged version of English proficiency test for non-native users and it has been used by not only International educational institution but also by several domestic higher learning institution as well as non educational agencies as a requirement of either admission, recruitment, or exit purpose. Some questionnaires are also used to collect data needed in this study. The questionnaire is motivation questionnaire taken from Schmidt, Boraie \& Kassabgy (1996).

\section{Procedure of Collecting Data}

At the beginning of the data collection, the proficiency test will be administered first. The students were gathered in a room and asked to work on the test as they are doing a TOEFL test. They were given 2 hours to work on the test. All questions are multiple choice and students answered questions by filling in an answer sheet. The tests evaluate skills in three areas: Listening Comprehension measures the ability to understand spoken English as it is used in colleges and universities, Structure and Written Expression measures recognition of selected structural and grammatical points in standard written English, and Reading Comprehension measures the ability to read and understand academic reading material in English. There are total of 140 items to be answer, the detail are given as following: 
Table 2. Time allocation for EFL proficiency test

\begin{tabular}{lcc}
\hline \multicolumn{1}{c}{ Section } & Number of Questions & Admin. Time \\
\hline Listening Comprehension & 50 & 35 minutes \\
Structure and Written Expression & 40 & 25 minutes \\
Reading Comprehension & 50 & 55 minutes \\
\hline TOTAL & 140 & 115 minutes \\
\hline
\end{tabular}

The reason to conduct TOEFL test as the first agenda is because this section is time consuming and requires high concentration of the students who take the test. Questionnaire will be carried out later after the students take a short break. Before distributing the three questionnaires to the participants, they are told that their identities are kept confidential and that no information revealing their identities is used in the study. They are given brief information about the purpose of the questionnaires, their scope, and their significance for EFL learning and teaching. Then the questionnaires are distributed to the participants. They are asked to fill identity questions before start answering the questionnaires. They were given an hour to answer all four set of questionnaires by the participants.

Table 3. The Administration of the Instrument in Data Collection

\begin{tabular}{lll}
\hline No & Time & Activity \\
\hline $\mathbf{1}$ & $09.00-09.20$ & Introduction \\
$\mathbf{2}$ & $09.20-11.00$ & TOEFL test \\
$\mathbf{3}$ & $11.20-11.30$ & Distributing Questionnaires \\
$\mathbf{4}$ & $11.30-12.30$ & Filling in questionnaire \\
\hline
\end{tabular}

\section{Data Analysis}

The first step in data analysis is scoring. This step is carried out after checking the students' answer sheet of the test and their response on questionnaire and the next step is to decide whether or not the answer sheets are appropriate to be scored. After that, the students' answers obtained from the proficiency test and questionnaires are scored; for the proficiency test, the answer will be corrected dichotomously in which the correct answer is scored 1 and the wrong answer is 0 . Then, the total score of TOEFL test will be based on the scoring criteria by ETS. For the questionnaire, the scoring will range from 15 since there are five options which can be chosen based on the students' opinion. The range score of item started with "strongly disagree" which is scored 1 to "strongly agree" scored as 5 . After that, the following step is data management. The result of scoring is put on table of data recording in order to make it easy for the data analysis. The table contains the identity of participant and their score in both TOEFL test and questionnaire. The table will present the score for each. Next, descriptive statistic data analysis is conducted to reveal the characteristics of the data concerning the variables under investigation which are motivation and students' EFL proficiency score. The characteristics of the data involve the frequency of distribution, measures of central tendency and measures of variability. The last, the scores are computed and analyzed using Pearson correlation to reveal the relationship among the two variables which measures the strength and direction of linear relationships between variables. 


\section{Findings and Discussion}

The result of the data collected is then descriptively analyzed. It aims at presenting the characteristics of the data related to the variables being investigated in the study; motivation and their EFL proficiency. The analysis includes the statistics of the data like maximum scores, minimum scores, mean, median, mode, standard deviation, and so on. The more detail presentation of the descriptive data analysis is presented in the appendix. The following is presented as the summary of the descriptive statistic analysis.

Table 4. Descriptive Statistics of Students' Motivation

\begin{tabular}{ll}
\hline Measures & Statistical Values \\
\hline $\mathrm{N}$ & 195 \\
Mean & 119.74 \\
Median & 120.06 \\
Mode & 118 \\
Std. Deviation & 12.272 \\
Range & 89 \\
Minimum & 63 \\
Maximum & 152 \\
\hline
\end{tabular}

The mean, median and mode of the data from the respondents' score on motivation are 119.74, 120.06 and 188 respectively. The small differences appear among the values implies that even though the data are not exactly normally distributed but is close to normal distribution. The range and the standard deviation (SD) values shows that the data of respondents' score on motivation varies since the range is 89 and SD is 12.272 .

\section{Students' EFL Proficiency towards English Learning}

Table 5 shows the descriptive statistics of the respondents' statistics data on motivation. The scores collected from the TOEFL test are analyzed and the result is reported as follows;

Table 5 Descriptive Statistics of Students' EFL Proficiency

\begin{tabular}{ll}
\hline Measures & Statistical Values \\
\hline $\mathrm{N}$ & 195 \\
Mean & 403.44 \\
Median & 387.00 \\
Mode & 377 \\
Std. Deviation & 60.232 \\
Range & 290 \\
Minimum & 297 \\
Maximum & 587 \\
\hline
\end{tabular}

As seen from Table 5, the mean, median and mode of the respondents' score on EFL proficiency show high difference. It means the data are exactly normally distributed. So is the range and the standard deviation which are significantly high compared to other previously presented variable. 


\section{Motivation Significantly Contributes toward EFL Proficiency}

The hypothesis for this statement is formulated as follows:

$\mathrm{H}_{0}=$ Students' motivation doesn't significantly correlate with students' EFL proficiency

$\mathrm{H}_{1}$ = Students' motivation significantly correlate with students' EFL proficiency

Based on the coefficient table, the value of $r$ is 0.217 ( $\operatorname{sig} 2$ tailed $=.002$ ), It is proved by the test of hypothesis in which $P$ Value $(.002)$ is lower than Alfa $(\alpha=0.01)$. it means that $\mathrm{Ho}$ is not rejected. Therefore, there is no significant contribution of students' motivation towards their EFL proficiency.

Based on the result of the study, it is found out that there is a significant correlation between students' L2 motivation and their EFL proficiency. The evidence shows that there is a significant correlation between those two variables, though the correlation is classified as low positive correlation. It means that we can predict students' proficiency regarding to their motivation in learning English as second language. There is positive correlation found means that the increase of students motivation can make an increase in students' EFL proficiency.

In addition, this study also confirming the result by Hee Lee (2011) who investigated the relationship between motivational factors and language learners' proficiency improvement has been chosen for closer examination. Ninety-two first-year Korean university students who took a mandatory English course for one semester participated in this study. They completed a questionnaire on their motivation to learn English and answered short essay questions related to their preferences in English courses; they also provided demographic information. Data analysis indicates that the participants consider English the cornerstone for their success in life regardless of their major. Means for instrumental and integrative motivation were higher than those for intrinsic motivation and interest. Group differences for all four factors were statistically significant. However, interest was the sole factor that contributed to improvements in the participants' scores. These results are expected to provide language teachers and researchers with ways to prevent possible demotivation and to eventually enhance effectiveness of language learning by aiding them with a better understanding of language learning motivation.

The current study was also in line with the previous theories that support motivation as the main predictor of students' success in acquiring language proficiency (Renandya, 2013; Dornyei, 2009; Shikawari, 2007; Yokochi, 2003; Norris, 2001). In the first language acquisition, motivation is not a divine factor because language learners are exposed with lots of input however in second language context input is limited and motivation plays important factor. The more motivated a L2 learner is, the faster and the better they will acquire the language. 


\section{Conclusion}

There is a weak positive correlation between L2 motivation and EFL proficiency. It implies that the increase in students' motivation may result in an increase in students' EFL proficiency. The result of the study supports the previous findings and theories that put motivation as the main important that can determine the students' success in acquiring English as foreign language.

\section{References}

Dörnyei, Z. (2009). The L2 motivational self system. Motivation, language identity and the L2 self, 36(3), 9-11.

Genç, B., \& Bada, E. (2010). English as a World Language in Academic Writing. Reading Matrix: An International Online Journal, 10(2).

Graham, S. (1997). Effective Language Learning. Clevedon: Multilingual Matters Ltd.

HeeLee, E. (2011). Relationship between motivation and proficiency improvement. 언어연구, 28, 405-430.

Norris-Holt, J. (2001). Motivation as a contributing factor in second language acquisition. The Internet TESL Journal, 7(6), 1-8.

Renandya, Willy A. (2015). L2 motivation: Whose responsibility is it? English Language Teaching, 27(4), 177-189.

Renandya, Willy A. (2013). Current Beliefs in ELT and Their Implications. Plenary paper presented at UNS, Surakarta, Indonesia, 18 May 2013

Richards, J. C. (2010). Competence and Performance in Language Teaching. RELC Journal, 41(2), 101-122.

Schmidt, R., Boraie, D., \& Kassabgy, O. (1996). Foreign language motivation: Internal structure and external connections. In Rebecca Oxford (Ed.), Language Learning Motivation: Pathways to the New Century. (Technical Report \#11) (pp. 9-70). Honolulu: University of Hawai'i, Second Language Teaching \& Curriculum Center.

Sikhwari, T. D. (2007). The Relationship between Affective Factors and the Academic Achievement of Students at the University of Venda. South African Journal of Higher Education, 21(3), 520-536.

Sulistyo, G. H. (2009). TOEFL in a Brief Historical Overview from PBT TO IBT. Bahasa dan Seni, Tahun 37, No.2, Page 116-127

Takahashi, A. \& Takahashi, H. (2013). Learners' Self-esteem and Its Relationships with Motivation for Learning English, Self-perceived and Actual English Proficiency. 新潟大学言語文化研究, Vol. 18, pg.1-12 http://hdl.handle.net/10191/23942

Vinke, A. A., \& Jochems, W. M. G. (1993). English Proficiency and Academic Success in International Postgraduate Education. Higher Education, 26(3), 275-285.

Yokochi, L. (2003). Affective Factors in Second Language Acquisition: A Critical Review of the Literature. (Unpublished thesis). Morgantown: Department of Foreign Languages, Eberly College of Arts and Sciences at West Virginia University. 